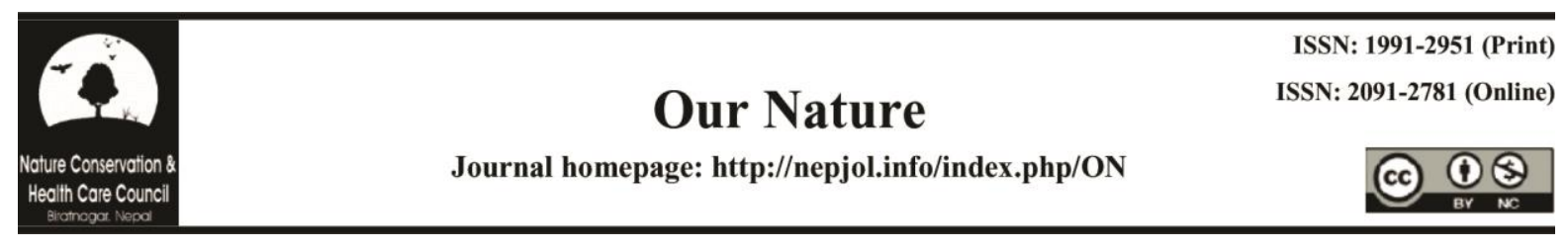

\title{
Length-Weight Relationship of Longtail Hillstream catfish Olyra longicaudata (McClelland, 1842)
}

\author{
Samjhana Shrestha*, Anjali Risal and Jay Narayan Shrestha \\ Department of ZoologyPost Graduate Campus,T.U.Biratnagar, Nepal \\ ${ }^{*}$ E- mail: sthasamjhana1389@gmail.com
}

\begin{abstract}
The present study reports the length weight relationshipof Olyralongicaudata from Chisang River, Nepal. Study was carried out in 30 fishes collected from April 2019 to Jul 2019. The body weight ranged from 0.8 to $5.2 \mathrm{~g}$ and total length from 6.1 to $13.4 \mathrm{~cm}$. Regression analysis was done to analyzed the data. The growth performance of length-weight relationship is found to be highly significant $(\mathrm{r}=0.936)$. The fish was found to show isometric growth pattern with exponential value (b) equal to 2.5115 .

keyword: Length-Weight relationship, Negative allometric growth, Olyra longicaudata.
\end{abstract}

DOI: http://doi.org/10.3126/on.v17i1.33990

Manuscript details: Received: 10.10.2019/ Accepted: 14.11.2019

Citation: Shrestha. S., A. Risal and J.N. Shrestha 2019. Length-Weight Relationship of Longtail Hillstream catfish

Olyralongicaudata(McClelland, 1842). Our Nature 17 (1): 32-35. DOI: http://doi.org/10.3126/on.v17i1.33990

Copyright: Shrestha, Risal and Mahaseth 2019. Creative Commons Attribution - Non Commercial 4.0 International License.

\section{Introduction}

It is common that growth of fish or any other organism increases with the influence in body length. When an organism grows, its length and weight increases simultaneously; as growth is a function of length and weight (Dars et al., 2010). Generally, fishes grow isometrically obeying the Cube law $\left(\mathrm{W}=\mathrm{L}^{3}\right)$ (Brody, 1945, Lagler, 1952). But there is every possibility of deviation of length weight relationship from Cube's law due to different environmental factors that changes the physico-chemical parameters of water where different species of fishes reside. Thus, Le-Cren(1951) modified Cube's law as $\mathrm{W}=\mathrm{aL}^{\mathrm{b}}$ to get a satisfactory result from the calculation of data obtained from the measurement of length and weight for their relationship throughout the life history stages of fishes. Several workers viz, Subba and Gosh (2000), Soomro et al.(2007), Muchlisin et al.(2010), Saikia et al.(2011), Dan-Kishiya (2013), Rahaman et al.(2015), Farado-nbeh et al.(2015), Panda and Datta (2017), Singh and Serajuddin (2017), Subba et al.(2018), Sinha et al.(2018), etc. have studied the length-weight relationship in different fish species. In fishery ractice, knowledge of length weight relationship reveals the poundage of fish caught, measure of produce from data on number and sizes of fish and also helps in easy assessment of growth rate, appearance of first maturity, time of spawning, status of stock variation, growth dynamics, general well-being of fishes etc.An already established length-weight relationship may be useful for assessing the data that contains only length frequency measurements and also helpful in setting up of yield equations, estimate the number of fishes landed and for comparing the population over space and time (Beverton and Holt, 1957).

Olyra longicaudata (McClelland, 1842) is a freshwater longtail hillstream catfish native to India where it occurs in Darjeeling Himalaya and Assam, and Myanmar, where it occurs in Tenassarim, also found in Thailand. In Nepal it was reported from the Kadya river(a tributary of Trijuga river), in Saptari district and from 


\section{Our Nature | December 2019 | 17 (1): 37-40}

Chisang river basin,Letang, Morang (Subba, 1995 and Subba et al. 2017). It is locally named as Sanosinghi. This species grows to a length of $15 \mathrm{~cm}$ in total length. This fish is usually a bottom dweller and inhabits in streams and hides under rocks and gravels(Kachari et al. 2014). The fish prefers shallow and clear cold running water with high level of dissolved oxygen enriched with larval and aquatic insects, crustaceans, annelids, molluscs, etc. (Kachari et al. 2014).

Indent the present study, while searching the fish around the potential habitats, the fish was found in the watercress, Rorippa nasturtiumaquaticum (simsag) cultivated terraces, hidden under the plant roots and small creeks. It is listed as least concerned fish in IUCN red list category (2010). The data on length-weight relationship is considered to be scanty for this species so the present study was aimed to predict the length weight relationship and provides the guideline information.

\section{Materials and methods \\ Study area}

Study site was Chisang river basin of Letang(Lat $26^{\circ} 45^{\prime} 46.3^{\prime \prime} \mathrm{N}$ and Long. $87^{0} 30^{\prime}$ '01.5”) close to Lamitar, at elevation of $291 \mathrm{~m}$.

\section{Sample collection}

A total 30 species were collected from April 2019 to July 2019. Taking into consideration as a rare fish of Nepal, less number of fish were caught. Total length of the fish (from snout to tip of caudal fin) was measured using a scale (cm), while weight was determined as total weight (Wt.) including gut and gonads using a digital balance.

\section{Data analysis}

The length-weight relationship of the fish under investigation was worked out as per cube law given by Le- Cren (1951).

$\mathrm{W}=\mathrm{aL}^{\mathrm{b}}$

Where, $\mathrm{W}$ is the weight of the fish,

$\mathrm{L}$ represents the observed total length of the fish, ' $a$ ' is the regression intercept and

' $b$ ' is the regression slope.

The logarithmic transformation of the above equation is,

$\log W=\log a+b \log L$

The length-weight relationships were determined by linear regression analysis. Relationship equations were determined by using least square method and the coefficient of correlation (r) was calculated by standard statistical formula. Scatter plot diagrams were plotted for total weight and lengths of the fishes. Statistical analysis was done in Excel.

\section{Results}

In present study, the body weight of Olyra longicaudata showed increasing trend with the increase in total body length. The body weight ranged from 0.8 to $5.2 \mathrm{~g}$ and total length from 6.1 to $13.4 \mathrm{~cm}$.

When the values of weight were plotted on the co-ordinate(y-axis) and those values of total length on abscissa(x-axis) they gave straight line as shown in figure 1 .

Regression equation for length-weight

$$
\mathrm{WT}=0.0099 \mathrm{TL}^{2.5115}
$$

$\log \mathrm{Wt}=2.5115 \log \mathrm{TL}-2.003$

The exponent $\mathrm{b}$ value for total length weight relationship is 2.5115 . Froese (1998) recommended that the exponent (b) of the length weight relationships should fall within the expected range of 2.5-3.5. 
Our Nature | December 2019 | 17 (1): 37-40

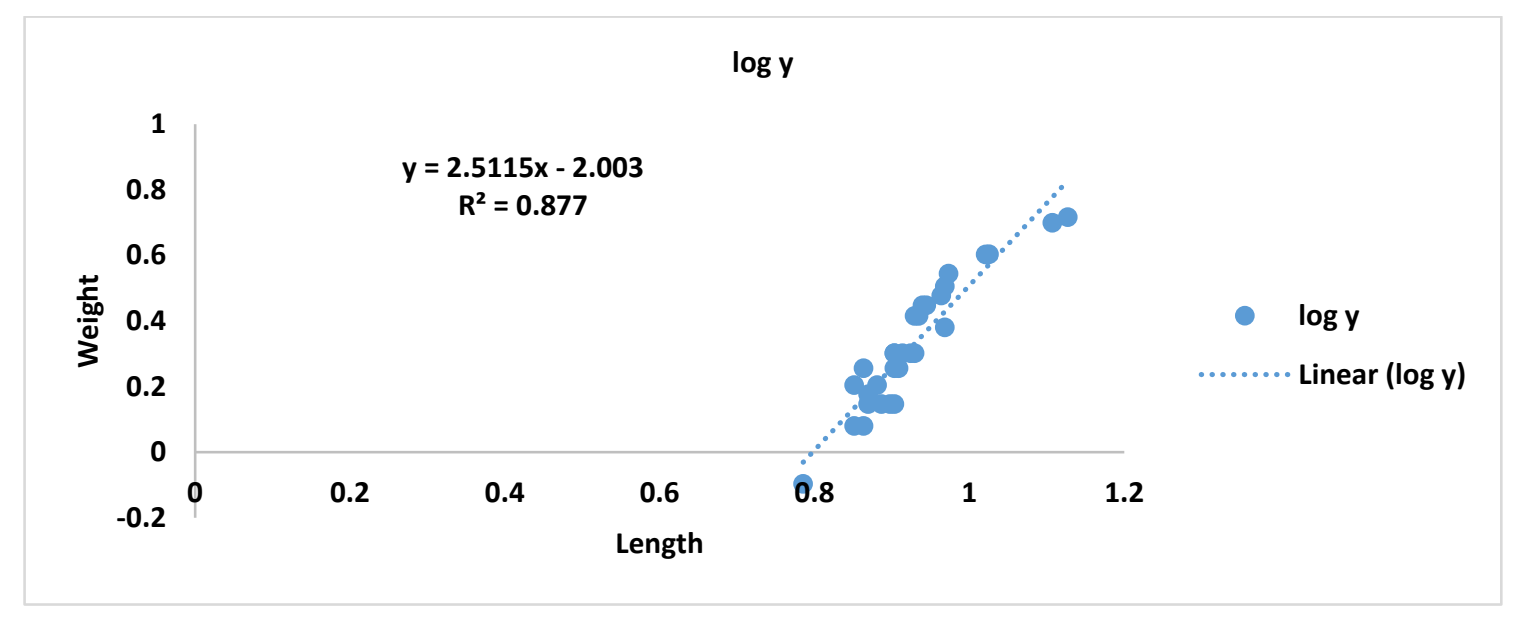

Figure 1.Graph showing relationship between length and weight of Olyra longicaudata The value for correlation coefficient (r) for length weight relationship parameter was 0.936 which revealed that the growth performance in Olyra longicaudata are highly significant.

\section{Discussion}

The calculated $\mathrm{b}$ value in the present study is 2.5115 which shows the negative allometric growth $(b<3)$. Variation in 'b' value can be attributed due to feeding (Le-Cren, 1951), sex (Hile and Jobes, 1940), developmental stages of gonads, specially the ovary affect the weight (Hile, 1936) and state of maturity (Frost, 1945). However, these factors were not accounted for in the present study. Similar finding was reported byDan-Kishiya (2013) in Tilapia zilli, Tilapia mariae, Oreochromis-niloticus, Barbus occidentalis and Barilius loati. Negative allometric growth was also observed on some freshwater fish species (Sarkar et al., 2013). Indent the present study provides an information on Length weight relationship for Olyra longicaudata.

\section{References}

Beverton, M.A. and S.J. Holt1957. On the dynamics of exploited fish populations, U.K. Ministry of Agriculture and Fisheries. Fisheries Investigation Series2(19): 533

Brody, S. 1945. Bioenergetics and growth. Reichold Publishing Corporation, New York.

Dan-Kishiya, A.S. 2013. Length-weight relationship and condition factor of five fish species from a tropical water supply reservoir in Abuja, Nigeria. American Journal of Research Communication 1(9): 175-18.

Dars, B.A., N.T. Narejo and A. Dayo 2010. Relative condition factor and length-weight relationship of a carp, Labeogonius
(Hamilton) from Keenjhar Lake, district Thatta, Sindh, Pakistan. Sindh Univ. Res. Jour. (Sci. Ser.). 42 (2): 67-70.

Faradonbeh, M.Z., S. Eagderi andF. Ghojoghi 2015. Length-weight relationship and condition factor of seven fish species of Totkabon River (southern Caspian Sea basin), Guilan, Iran. International Journal of Aquatic Biology3(3): 172-176.

Froese, R. 1998. Length weight relationship for 18 less studied fish species. Journal of Applied Ichthyology 14: 117-118.

Frost, W.E. 1945. The age and growth of eels (Anguilla anguilla) from the Windermere catchment area. J Anim Ecol 2(4): 106-124.

Hile, R. 1936. Age and growth of the Cisco leucichthysartedi (Lesueur) in the lake of Northeastern highlands Wisconsin. Bulletin of the United States Bureau of Fisheries48: 211-317.

Hile, R. and F.W. Jobes 1940. Age, growth and production of the yellow perch Perca flavescens (Mitchill), of Saginaw Baya.Trans Am Fish Wash48:211-217.

IUCN, 2010. The IUCN Red list of threatened species. International Union for Conservation of Nature and Natural Resources. http://www.iucnredlist.org/

Kachari, A., B. Gogoi, R. Dutta, K. Aran, P. Ghosh, S. Maitra, S. Bhattacharya and D.N. Das 2014. Habitat preference of an endangered Hill Stream Catfish Olyralongicaudata (McClelland) from Arunachal Pradesh, India. Int. J. Fish. Aquat. Stud1: 86-93. 


\section{Our Nature | December 2019 | 17 (1): 37-40}

Lagler, K.F. 1952. Freshwater Fishery Biology. Wim C Brown Co. Dubugue, Iowa.

Le-Cren, E.D. 1951. The Length-Weight Relationship and Seasonal Cycle in GonadWeight and Condition in the Perch (Perca fluviatilis).J Anim Ecol20:201-219.

Muchlisin, Z.A., M. Musman and M.N. SitiAzizah 2010. Length-weight relationships and condition factors of two threatened fishes, Rasbora tawarensis and Poropuntius tawarensis, endemic to Lake Laut Tawar, Aceh Province, Indonesia. Journal of Applied Ichthyology26: 949-953.

Panda, A and M.K. Datta 2017. Length-weight relationship and Relative condition factor of Barilius bendelisis (Hamilton, 1807) and Barilius barna (Hamilton, 1822) from Manu River, Tripura, India. Journal of Entomology and Zoology Studies5(6): 2535-2539.

Rahman, A., K. Talukdar, W. Rahman and P. Deka 2015. Length-Weight relationship and relative condition factor of Anabas testudineus (Bloch) of Deepar Beel (wetland) of Assam, India. International Journal of Applied Research1(11): 956-958.

Saikia, A.K, A.S.K. Singh, Das, D.N and S.P.Biswas 2011. Length Weight relationship and condition factor of spotted snakehead, Channa punctatus (Bloch). Bulletin of Life Science 17:102-108.

Sarkar, U.K., G.E. Khan, A. Dabas, A.K. Pathak, J.I. Mir, S.C. Rebello, A. Pal and S.P. Singh 2013. Length weight relationship and condition factor of selected freshwater fish species found in River Ganga, Gomti and Rapti, India. Journal of Environmental Biology 34: 951-956.

Singh, M. and M. Serajuddin 2017. Lengthweight, length- length relationship and condition factor of Channa punctatus collected from three different rivers of India. Journal of Entomology and Zoology Studies5(1): 191-197.

Sinha, A.K., P. De, A. Das and S. Bhakat 2018. Studies on length-weight relationship, condition factors and length-length relationship of Anguilla bengalensis bengalensis (Gray, 1831) (Actinopterygii, Anguillidae) collected from River Mayurakshi, Siuri, Birbhum, West-Bengal, India. International Journal of Fisheries and Aquatic Studies 6(4): 521-527.

Soomro, A.N., W.A. Baloch, S.I.H. Jafri and H. Sujuki 2007. Studies on length-weight and length-length relationships of catfish, Eutropichthyesvacha(Hamilton)

(Schibeidae: Siluriformes) from Indus river, Sindh, Pakistan. Caspian J. Env. Sci. 5(2): 134-135.

Subba, B.R. 1995. Report on the occurrence of a hill stream fish, Olyralongicaudata (McClelland, 1842), Siluriformes, Olyridae from Kadya River of Nepal. Freshwater Biology 7(2): 155-157.

Subba, B.R. and T.K. Ghosh 2000. Lengthweight relationship of a hill-stream fish, Glyptothoraxtelchitta (Ham.) from Saptakoshi River of Nepal. Journal of the Indian Fisheries Association 27: 79-82.

Subba, B.R., N. Pokharel and M.R. Pandey 2017. Ichthyo-faunal diversity of Morang district, Nepal. Our Nature15(1-2): 55-67.

Subba, S., B.R. Subba and V.K. Mahaseth 2018. Relative condition factor, length-weight relationship and sex ratio of copper mahseer,Neolissochilushexagonolepis (McClelland, 1839) from Tamor River, Nepal Our Nature16(1):27-34. 